\title{
OCCURRENCE OF CHIRONOMID LARVAE LIVING INSIDE FALLEN-FRUITS IN ATLANTIC FOREST STREAMS, BRAZIL
}

\author{
Fabio de Oliveira Roque(1), Tadeu Siqueira \\ \& Susana Trivinho-Strixino
}

\section{Resumo}

Ocorrências de larvas de Chironomidae (Diptera) em frutos caídos em córregos da Mata Atlântica, Brasil - Larvas de Chironomidae exploram uma grande variedade de habitats e tipos de alimentos. Neste estudo, nós documentamos a ocorrência de larvas vivendo dentro de frutos caídos em córregos de baixa ordem na Mata Atlântica, Brasil. Nós encontramos larvas minando o tecido de frutos de 12 espécies de árvores. Sete morfoespécies de Endotribelos foram identificadas, incluindo as espécies E. albatum and E. grodhaus, encontradas pela primeira vez no Brasil. Os resultados indicam que larvas de Endotribelos constituem o grupo de insetos mais comum em frutos caídos em córregos da Mata Atlântica.

Palavras-chave: Comportamento alimentar, Endotribelos, Diptera, Região Neotropical

(1) Departamento de Biologia, Faculdade de Filosofia, Ciências e Letras de Ribeirão Preto, Universidade de São Paulo, Avenida Bandeirantes 3900, Bairro Monte Alegre, CEP: 14040-901 Ribeirão Preto, SP, Brasil. E-mail: rtaminato@uol.com.br; (2) Laboratório de Entomologia Aquática, Departamento de Hidrobiologia, Universidade Federal de São Carlos, Rodovia Washington Luís (SP-310), Km 235, CEP: 13565-905 São Carlos, SP, Cx. Postal 676, Brasil. 


\section{Abstract}

Occurrence of chironomid larvae living inside fallen-fruits in Atlantic Forest streams, Brazil - The Chironomidae larvae explore a wide variety of habitats and kinds of food. In this study we reported the use of fallen-fruits by chironomid larvae in low order streams in the Brazilian Atlantic Forest. We found chironomid larvae mining fruit tissue of 12 tree species. Seven morphospecies of Endotribelos were identified, including the species E. albatum and E. grodhaus found for the first time in Brazil. Our results suggest that larvae of Endotribelos are the commonest insect group living inside fallen-fruits in streams.

Key words: Feeding behavior, Endotribelos, Diptera, Neotropical region

\section{Introduction}

The Chironomidae larvae explore a wide variety of habitats and have a great diversity of kinds of food and feeding behaviors. They have been reported using a variety of plant-derived food resources, including parts of higher plants that fall in aquatic systems, such as wood and leaves (Pinder, 1986; Berg, 1995). This subject has been studied in different regions of the world. In the Neotropical region, particularly in the Brazilian Atlantic Forest, although some studies have been carried out about the distribution of Chironomidae larvae in different stream habitats (Sanseverino \& Nessimian, 1998; Sanseverino \& Nessimian, 2001; Henrique-Oliveira, 2003; Roque et al. 2003), none about Chironomidae in specific fallen-parts of plants in streams had been published.

The input of material from forest has been suggested as an important ecological driving force to the low order stream dynamic (Vannote et al., 1980). In the Atlantic Forest, the forest floor may receive up to $400 \mathrm{~kg} / \mathrm{ha} / \mathrm{yr}$ of fallen-fruits (Morellato, 1992) and the streams also receive a great amount (Henry et al., 1994). Although the fallen-fruits have been recognized as having important implications for aquatic and terrestrial ecology and dynamics, little information is available about their influence on stream invertebrate community.

Given the huge amount of fallen-fruits, the high diversity and density of Chironomidae lavae in streams of Atlantic Forest, and the quality of the fallenmaterial strongly affects Chironomidae population dynamics (Toscano \& 
McLachlan, 1980; Walentowics \& McLachlan, 1980), we decided to assess the use of fallen-fruits by Chironomidae larvae in low order Atlantic Forest streams.

\section{Material and Methods}

\section{The study area}

According to Morellato \& Haddad (2000) the Atlantic Forest is composed of two major vegetation types: the coastal forest or Atlantic Rain Forest and the tropical seasonal forest or Atlantic semi-deciduous forest. The Atlantic Rain forest covers mostly the low to medium elevation $(<1000$ $m$ a.s.I.) of the eastern slopes of mountain chain that runs along the coastline from southern to northeastern Brazil; the Atlantic-deciduous Forest extends across the plateau (usually $>600 \mathrm{~m}$ a.s.I.) in the center and southeastern interior of the country. The Atlantic Rain Forest experiences warm and wet climate without dry season; a seasonal climate with a relatively severe dry season (generally from April to September) predominates over the distribution of the Atlantic Semi-deciduous Forest.

This study was carried out in streams of 5 areas in Atlantic Forest in the State of São Paulo, three streams situated in Atlantic Rain Forest and two in Atlantic semi-deciduous forest. The general characteristics of the streams, where the fruits were collected, are given in Table I.

\section{Sampling}

After collecting the fallen-fruits in the streams, we transported them to the laboratory. When possible, the fruits were kept in an oxygenated aquarium in order to rear the chironomid larvae and obtain the adults. In this study only the specimens collected inside the fruits were considered. Because of the low resolution of taxonomic knowledge for Chironomidae in Brazil (Spies \& Reiss, 1996), it was difficult to identify specimens to the species level. Hence, individuals were identified up to the most specific taxonomic level possible, using available literature and they were separated as morphospecies. The specimens are deposited in the collection of the Laboratório de Entomologia Aquática do Departamento da Hidrobiologia da Universidade Federal de São Carlos, São Paulo, Brazil. 
Table I

General characteristics of the streams where the fruits were collected

\begin{tabular}{|c|c|c|c|c|c|}
\hline \multirow[b]{2}{*}{$\begin{array}{l}\text { General } \\
\text { Characteristics }\end{array}$} & \multicolumn{5}{|c|}{ Sites } \\
\hline & $\begin{array}{c}\text { Parque } \\
\text { Estadual } \\
\text { do Jaraguá }\end{array}$ & $\begin{array}{c}\text { Serra } \\
\text { do Mar, } \\
\text { Cananéia }\end{array}$ & $\begin{array}{c}\text { Serra } \\
\text { do Mar, } \\
\text { Cubatão }\end{array}$ & $\begin{array}{l}\text { Itirapina, } \\
\text { "Lagoa } \\
\text { que canta" }\end{array}$ & $\begin{array}{c}\text { São Carlos, } \\
\text { Fazzari } \\
\text { Stream }\end{array}$ \\
\hline $\begin{array}{l}\text { Predominant } \\
\text { vegetation }\end{array}$ & $\begin{array}{l}\text { Atlantic } \\
\text { Rain } \\
\text { Forest }\end{array}$ & $\begin{array}{l}\text { Atlantic } \\
\text { Rain } \\
\text { Forest }\end{array}$ & $\begin{array}{l}\text { Atlantic } \\
\text { Rain } \\
\text { Forest }\end{array}$ & $\begin{array}{l}\text { Riparian- } \\
\text { forested } \\
\text { formation }\end{array}$ & $\begin{array}{l}\text { Riparian- } \\
\text { forested } \\
\text { formation }\end{array}$ \\
\hline $\begin{array}{l}\text { Geographic } \\
\text { Coordenates }\end{array}$ & $\begin{array}{l}23^{\circ} 24^{\prime} \mathrm{S} \\
45^{\circ} 44^{\prime} \mathrm{W}\end{array}$ & $\begin{array}{l}24^{\circ} 54^{\prime} \mathrm{S} \\
47^{\circ} 58^{\prime} \mathrm{W}\end{array}$ & $\begin{array}{l}23^{\circ} 54^{\prime} \mathrm{S} \\
46^{\circ} 28^{\prime} \mathrm{W}\end{array}$ & - & $\begin{array}{l}21^{\circ} 57^{\prime} \mathrm{S} \\
47^{\circ} 50^{\prime} \mathrm{W}\end{array}$ \\
\hline Stream Order & 1 and 2 & 1 and 2 & 1 and 2 & 1 & 1 and 2 \\
\hline pH & 6.68 & 7.02 & 7.09 & 4.67 & 4.75 \\
\hline$O D(m g / l)$ & 6.98 & 10.9 & 8.7 & 5.83 & 6.95 \\
\hline $\begin{array}{l}\text { Conductivity } \\
(\mu S \mathrm{~cm}-1)\end{array}$ & 30 & 30 & 20 & 23 & 10 \\
\hline
\end{tabular}

\section{Results and Discussion}

Fleshy fruits belonging to 12 tree species were collected (Tab. II). Most of them have been reported as important food recourse for terrestrial insects (Pizo \& Oliveira, 2000). We found Chironomidae larvae mining fruit tissue of all tree species. Seven morphospecies of Endotribelos were identified (Tab. II). The species E. albatum Sublette \& Sasa, 1994 and E. grodhausi Sublette \& Sasa, 1994 have already been reported to the Neotropical region by Sublette \& Sasa (1994), but our study amplifies the South limit distribution of these species.

The occurrence of different Endotribelos morphospecies in fruits of different sites suggests a non-homogenous distribution of them in the Atlantic Forest (State of São Paulo), while the presence of the same 
Table II

Chironomidae (Diptera) collected in different fallen-fruits in low order streams of different sites of Atlantic Forest (São Paulo, Brazil)

\begin{tabular}{|c|c|c|c|c|c|c|c|}
\hline \multirow[b]{2}{*}{ Sites/ Fruits } & \multicolumn{7}{|c|}{ Taxa } \\
\hline & $\begin{array}{c}\text { Endotribelos } \\
\text { grodhausi }\end{array}$ & $\begin{array}{c}E . \\
\text { albatum }\end{array}$ & $\begin{array}{c}E . \\
\text { sp. } 1\end{array}$ & $\begin{array}{c}E . \\
\text { sp. } 2\end{array}$ & $\begin{array}{c}E . \\
\text { sp. } 3\end{array}$ & $\begin{array}{c}E . \\
\text { sp. } 4\end{array}$ & $\begin{array}{c}E . \\
\text { sp. } 5\end{array}$ \\
\hline \multicolumn{8}{|l|}{ P. E. Jaraguá } \\
\hline Euterpes edullis & $X$ & & & & & & \\
\hline Magnoliacea sp.1 & $x$ & & & & & & \\
\hline Myrtacea sp. 1 & $X$ & & & & & & \\
\hline Ficus sp. 1 & $X$ & & & & & & \\
\hline Fruit sp. 1 & $x$ & & & & & & \\
\hline \multicolumn{8}{|l|}{ Cubatão } \\
\hline Annonacea sp.1 & & & & & $X$ & & \\
\hline Ficus sp. 2 & & & & & $x$ & & \\
\hline Myrtacea sp. 2 & & & & & $x$ & & \\
\hline Rubiacea sp. 1 & & & & & $X$ & & \\
\hline \multicolumn{8}{|l|}{ Cananéia } \\
\hline Ficus sp. 2 & & $X$ & & & & & \\
\hline \multicolumn{8}{|l|}{ São Carlos } \\
\hline $\begin{array}{l}\text { Callophylum } \\
\text { brasiliensis }\end{array}$ & & & & & & $x$ & $x$ \\
\hline Talauma ovata & & $X$ & & & & & \\
\hline \multicolumn{8}{|l|}{ Itirapina } \\
\hline $\begin{array}{l}\text { Callophylum } \\
\text { brasiliensis }\end{array}$ & & & $x$ & $\mathrm{X}$ & & & \\
\hline Talauma ovata & & & $X$ & $\mathrm{X}$ & & & \\
\hline
\end{tabular}

morphospecies living in different fruits suggests low specific relationship between morphospecies and fruits. However, new studies are required to support this hypothesis.

Food quality affects chironomid population densities (Berg, 1995) and life history patterns (Ward \& Cummins, 1979), but is extremely difficult to define it, because some larvae may ingest a wide variety of foods (Pinder, 1986). The high amount of carbohydrates, proteins and lipids in some fruits suggest that they represent a rich food resource for the Chironomidae larvae (see Galetti et. al., 2000 and Pizo \& Oliveira, 2000 for some fruit nutritional information). Furthermore, microbial colonization probably make the fruits in decomposition more palatable and with a high nutritional value, as some studies about woody debris and macrophytes have demonstrated (Pinder, 1986; Berg, 1995). On the other hand, the anaerobic condition inside fallenfruits in decomposition and the presence of allelopathic substances in many 
Neotropical plants (Pizzamiglio, 1991) may difficult their colonization by Chironomidae larvae, except by Endotribelos.

According to Oliver (1971) few Chironomidae appear to be restricted rigidly to a single type of habitat and food, except some xylophagous groups, such as Stenochironomus, Xestochironomus (Borkent, 1984) and Xylotopus (Oliver, 1982). In the case of Endotribelos larvae, a strong tendency to penetrate leaves and stems of macrophytes was observed (Grodhaus, 1987). Sanseverino \& Nessimian (1998) found plant tissue, fungi and pollen in the stomach contents of Endotribelos larvae. Furthermore, Endotribelos (identified as Tribelos) have been reported in woods (Trivinho-Strixino \& Strixino, 1998), in macrophytes (Trivinho-Strixino \& Strixino, 1993; Trivinho-Strixino et al., 2000), and we have found them in the freshwater sponges Radiospongilla amazonensi and Metania spinata (unpublished data). These results suggest that although the larvae of Endotribelos may be the commonest insect group living inside fallen-fruits in aquatic systems, they are not restricted to them.

\section{References}

Berg, H.B., 1995. Larval food and feeding behavior. p. 136-168. In: The Chironomidae: Biology and Ecology of Non-Biting Midges. (P. D. Armitage, P.D., Cranston, P.S. \& Pinder, L.C.V. eds). Chapman \& Hall, London, $523 \mathrm{p}$.

Borkent, A., 1984. The systematic and phylogeny of the Stenochironomus complex (Diptera: Chironomidae). Mem. Entomol. Soc. Can.128:1-269.

Galetti, M., Laps, R. \& Pizo, M.A., 2000. Frugivory by Toucans (Ramphastidae) at two altitudes in the Atlantic Forest of Brazil. Biotropica 32:842-850.

Grodhaus, G., 1987. Endochironomus Kieffer, Tribelos Townes, Synendotendipes, n. gen., and Endotribelos, n. gen. (Diptera: Chironomidae) of the Nearctic Region. J. Kansas Entomol. Soc. 60:167-247.

Henry, R.; Uieda, V.S.; Afonso, A.A. O. \& Kikuchi, R.M., 1994. Input of allochthonous matter and structure of fauna in a brazilian headstream. Verh. Internat. Verein. Limnol. 25:1866-1870. 
Henrique-Oliveira, A.L.; Dorvillé, L.F.M \& Nessimian, J.L., 2003. Distribution of Chironomidae larvae fauna (Insecta: Diptera) on different substrates in a stream at Floresta da Tijuca, RJ, Brazil. Acta Limnol. Bras. 15:69-84.

Morellato, L.P., 1992. Sazonalidade e dinâmica de ecossistemas florestais na Serra do Japi. p. 97-110. In: História natural da Serra do Japi: ecologia e preservação de uma área florestal no sudeste do Brasil. (L.P. Morellato ed.) Editora da UNICAMP, Campinas, Brasil, 321 p.

Morellato, L.P. \& Haddad, C.F.B., 2000. Introduction: the Brazilian Atlantic Forest. Biotropica 32:786-792.

Oliver, D.R., 1971. Life history of the Chironomidae. Ann. Rev. Entomol. 12:211-230.

Oliver, D.R., 1982. Xylotopus, a new genus of Orthocladiinae (Diptera: Chironomidae). Can. Entomol. 117:803-809.

Pinder, L.C.V., 1986. Biology of Freshwater Chironomidae. Ann. Rev. Entomol. 31:1-23.

Pizzamiglio, A.A., 1991. Ecologia das interações inseto/planta p. 101-129. In: Ecologia Nutricional de Insetos e suas Implicações no Manejo de Pragas. (A.R. Panizzi, \& J.R.P. Parra, eds). Editora Manole Ltda e co-edição CNPq, 359 p.

Pizo, M.A. \& Oliveira, P.S., 2000. The use of fruits and seeds by ants in the Atlantic Forest of Southeast Brazil. Biotropica 32:851-861.

Roque, F.O.; Trivinho-Strixino, S.; Strixino, G; Agostinho, R.C. \& Fogo, J.C., 2003. Benthic macroinvertebrates in streams of the Jaraguá State Park (Southeast of Brazil) considering multiple spatial scales. J. Insect Conser. 7:63-72.

Sanseverino, A.M. \& Nessimian, J.L., 2001. Hábitats de larvas de Chironomidae (Insecta: Diptera) em riachos de Mata Atlântica no Estado do Rio de Janeiro. Acta Limnol. Bras. 13:29-38.

Sanseverino, A.M. \& Nessimian, J.L., 1998. Habitat preferences of Chironomidae larvae in an upland stream of Atlantic Forest, Rio de Janeiro State, Brazil. Verh. Internat. Verein. Limnol. 26:2141-2144. 
Sublette, J.E. \& Sasa, M., 1994. Chironomidae collected in Onchocerciasis endemic areas of Guatemala (Insecta, Diptera). Spixiana Suppl. 20:1-60.

Spies, M. \& Reiss, F., 1996. Catalog and bibliography of Neotropical and Mexican Chironomidae (Insecta, Diptera). Spixiana Suppl. 22:61-119.

Toscano, R.J. \& McLachlan, A.J., 1980. Chironomids and particles: microorganisms and chironomid distribution in a peaty upland river. $\mathrm{p}$. 171-177. In: Chironomidae: Ecology, Systematics, Cytology and Physiology. (D.A. Murray ed). Pergamon Press, Oxford. 354p.

Trivinho-Strixino, S. \& Strixino, G., 1993. Estrutura da comunidade de insetos aquáticos associados à Pontederia lanceolata Nuttal. Rev. Bras. Biol. 53:103-111.

Trivinho-Strixino, S. \& Strixino, G., 1998. Chironomidae (Diptera) associados a troncos de árvores submersos. Rev. Bras. Entomol 41:173-178.

Trivinho-Strixino, S.; Correia, L.S.C. \& Sonoda, K., 2000. Phytophilous Chironomidae (Diptera) and other macroinvertebrates in the ox-bow Infernão Lake (Jataí Ecological Station, Luiz Antônio, SP, Brazil). Rev. Bras. Biol. 60:527-535.

Vannote R.L.; Minshall G.W.; Cummins K.W.; Sedell J.R. \& Cushing C.E., 1980. The river continuum concept. Can. J. Fish. Aquat. Sci. 37:130-137.

Walentowicz, A.T. \& McLachlan, A.J., 1980. Chironomids and particles: a field experiment with peat in an upland stream. p. 179-185. In: Chironomidae: Ecology, Systematics, Cytology and Physiology. (D.A. Murray ed). Pergamon Press, Oxford. 354p.

Ward, G.M. \& Cummins, K.W., 1979. Effects of food quality on grouth of a stream detritivore, Paratendipes albimanus (Meigen) (Diptera: Chironomidae). Ecology 60:57-64. 